\title{
Roundtable: The FIFA World Cup 2010 in the News
}

\author{
Facilitators: Peter Alegi and Chris Bolsmann \\ Participants: Simon Kuper, Rodney Reiners, and John Turnbull
}

\section{Introduction}

Despite the presence and achievements of individual African footballers in Europe's top leagues and the improvements in communication technology (the Internet and satellite television, among others), African football remains offlimits and a mystery to most Western media observers as well as Western fans.1 Selective and deficient media coverage of the continental game also has much to do with it. Consequently, before the 2010 World Cup, South Africa still remained a closed book to many. Only a few journalists and researchers have bucked the trend, writing about African football in its entirety. Before the World Cup, Peter Alegi, probably the foremost historian of African football, gathered a panel of journalists and researchers to discuss the significance of the World Cup for the African continent. Their comments in January 2010, as recorded here for this special FIFA World Cup 2010 edition of Ecquid Novi: African Journalism Studies, are interesting to read in the aftermath of the competition's successful South African run (that is in terms of on the field excitement, pristine stadiums, and organization). The host team, South Africa, was not so lucky, having bowed out in the first round. As a postscript to the roundtable, Peter and his co-facilitator for the roundtable, sociologist Chris Bolsmann, sat down post-World Cup to put the tournament into perspective.2-Guest Editor

\section{Q1. What does FIFA's decision to award the World Cup finals mean for South Africa and world football in general?}

Simon Kuper: I think the initial impetus was simply to assuage African anger. Many Africans seem to have felt their exclusion from hosting the World Cup as deeply as their exclusion from having a permanent seat on the UN Security Council, a symbol of Africa's exclusion from the world's top table. Africa has enough members of FIFA to kick up a fuss about this, and for electoral reasons Blatter pacified them. The dressing-up of this diplomatic decision in a kind of nineteenth-century pantomime of Africa-happy smiling black faces, lions and elephants, talk of doing good for the poor world—only came later.

For world football the award of the World Cup is about righting a wrong- once and then never again. After this World Cup, the tournament will not come back to Africa in our lifetimes.

Having a World Cup in Africa allows the rich world to pat itself on the back: "Look how kind we are to poor people." FIFA's propaganda films and some TV documentaries I've seen show images of young black South Africans kicking a football around bumpy pitches; energetic hopeful people who want a better future. That is the official face of this World Cup.

What does it mean for South Africa? The 1995 Rugby World Cup was experienced as a moment in nation building; people of all racial backgrounds getting behind one South African team, the creation of a color-blind South African nationalism where none had existed pre-1994. The football World Cup will not have much political meaning. It was cast by Mbeki, by the South African ruling class of his era, by FIFA, by the South African media, and hence also by ordinary South Africans above all as an economic event. The World Cup would make South Africa richer, it would enhance development, the infrastructure spending would pay off over 
the long term, and the successful tournament would spark the surge of foreign investment that post-apartheid South Africa has long been awaiting.

Unfortunately, these economic claims are bogus. The World Cup will not help the South African economy. Most academic economists agree that hosts of sporting events do not get richer from hosting. Let us hope that not all the wasteful spending will actually damage the South African economy, or its under-funded schools and hospitals too much. If you ask what the World Cup means to South Africa, the tournament is understood inside the country largely as an economic event-even though that understanding is flawed.

Rodney Reiners: For South Africa, hosting the World Cup finals is the culmination of the amazing turnaround this country has undergone. From pariah status many years ago, because of the brutal, hated apartheid regime, South Africa is now the belle of the ball. Eyes will be focused on this nation for positive reasons, rather than for the atrocious human abuses that took place here in the recent past. South Africa still has its problems, and there are many, but the World Cup also allows it to address a few of those issues. For example: All over the country, road improvements are taking place as part of the World Cup preparations, public works that would otherwise have taken much longer or maybe would not have seen the light of day. Thus, football has ensured that the road chaos so often endemic to this country will be alleviated.

For world football, this is the opportunity to see Africa as progressive, not as the backward continent the rest of the world believe it to be. This is the chance for Africa to show that it is capable of being "world class." This is the time to slay the Afro-pessimists and doomsayers. The emergence of African footballers on the world stage over the last two decades has been meteoric and this is the moment where African footballers can say: "This is our continent, this is where we come from, and this is where we learnt our football.”

John Turnbull: First, I must emphasize my position as an outsider, some 8,400 miles—with transit through Dakar, Senegal - away from the host cities of 2010. I run a Web site on world football from Atlanta in the United States, which also places me at considerable distance from the decision makers in Zurich. My interest is in what 2010 will mean for South African footballers and organizers on the margins. From this perspective, I am influenced by skepticism among some activists and scholars who wonder how a nation once known for its culture of resistance might assimilate unchecked avarice in the guise of a thirty-two-nation football tournament. My biases are such that, instead of the question above, I am tempted to ask how FIFA's decision to award the World Cup finals to South Africa might harm the country and world football.

Through a mixture of planning and coincidence, I was able to the sit at the same table in Cape Town in June 2009 with three individuals with unique perspectives on the upcoming tournament. Two of them, Sedick Isaacs and Marcus Solomon, were key figures in the prisoners' football league on Robben Island, the notorious apartheid prison where Nelson Mandela and many other activists were incarcerated. Their stories are well told in the book by Chuck Korr and Marvin Close, More Than Just a Game (2008). The third person in the conversation was Florian Zech, who operates grassroots football leagues for children's homes in Cape Town as well as midnight football programs in Khayelitsha- a black township of almost a million people twenty miles from the center of Cape Town. The organization's name is Amandla Ku Lutsha.

Since his time on Robben Island, Solomon in his own advocacy group, the Children's Resource Centre, has witnessed to sport's transformative potential—a natural extension of what football matches and other sports did for Robben Island prisoners. In the range of views concerning the forthcoming World Cup, Solomon sounds among the most antagonistic. He believes the tournament does not belong in the country. For his honesty and passion with which he expresses his opinion, I find his statements worthy of consideration. "I can take you to any township now. The children are just sitting around. A stadium in Khayelitsha is during the week a grazing ground for a few people's cattle. I am involved with a project where we struggle. And this government can spend that amount of money”-_some US\$600 million on Green Point Stadium on the Cape Town waterfront, 
not far from Khayelitsha. Solomon laments the influence that the South African government has allowed FIFA to exert over spending on public transport, for example, and on new stadia. Schools lack proper sport programs, and while Western Cape officials speak about World Cup-themed curriculum under development, it is not clear how the paucity of recreation opportunities is going to be addressed, other than refurbishing stadia in black working-class areas (known as the Cape Flats) for use as training centers. On the trickle-down legacy championed by FIFA's government liaisons in the Western Cape, Solomon says, "It's not even a distortion. It is a lie, and they know that. ... FIFA gives a few balls, and they put up one of those billboards showing children kicking a ball. It’s scandalous.”

Others take a more moderate view. Zech, for example, says that FIFA's job is to run a soccer tournament, not to provide development initiatives. Some grassroots organizations will benefit more than others will. His group has found creative ways to work alongside Grassroots Soccer, the FIFA-backed nonprofit organization that will operate the Football for Hope Centre that opened in Khayelitsha in December 2009. Zech sounds skeptical that FIFA will succeed in its goal of opening 19 additional centers, designed to join football to a public health and education mission across the continent.

The best indicator of what the tournament means for South Africa is a response from a guide at Robben Island Visitor Centre. A former political prisoner himself, he said he could not afford tickets to World Cup matches combined with transit to and from home. He said he would think about buying a slightly bigger television.

\section{Q2. The South African organizers have repeatedly referred to an "African” tournament, event, and spectacle. Do you see the event as such?}

JT: I am not sure that the 2010 World Cup will be a (South) African tournament in the broadest sense, much less an event for building Pan-Africanism. Globalization has created new appetites. Children having a winterholiday kick about at a school beside the Hector Pieterson Memorial in Soweto looked forward to seeing African superstars of the English Premiership-Didier Drogba of Côte d'Ivoire, Michael Essien of Ghana, John Obi Mikel of Nigeria—competing on South African soil. They even spoke highly of Bafana Bafana [South Africa's national soccer team], an optimism that must dwindle with adulthood.

Not many that I spoke to, however—perhaps because they were too young — shared the view of some South African organizers that the 2010 event sits on a continuum with anti-apartheid advocacy and African independence. Some offi- cials see the World Cup as a natural consequence of earlier resistance, almost a reward for it. "We wouldn't be where we are today if those youth in 1976 did not actually rise up and start the process which led to the 1994 elections," said Rich Mkhondo, spokesperson for the 2010 Local Organising Committee, referring to the Soweto uprising, a crucial event that revived the liberation struggle and helped bring down the apartheid system.

For FIFA, the South African tournament solidifies the world governing body's paternalistic relationship to Africa and highlights the nation's importance in facilitating the rise to power of FIFA president João Havelange and successor, and current president, Sepp Blatter. Paul Darby has researched how the organization's antiapartheid lobby played a critical role in elevating Havelange and, by extension, Africa's place in world football. A Pan-African World Cup sounds like FIFA ideal rather than reality.

Kaizer Motaung, founder and chairperson of Kaizer Chiefs, the most popular club in South Africa, emphasizes the importance of national resources in securing the World Cup. In Motaung's version of events, he, Danny Jordaan (2010 World Cup LOC [Local Organizing Committee] Chief Executive Officer) and other South African football officials broached the possibility of hosting the event in 1994, less than two months after South Africa's first independent elections. Soccer, along with the 1995 Rugby World Cup, formed part of the narrative of national redemption, and not just for Motaung. Football continues to engage the tangible desire within South 
African life for transcendence. In a post-apartheid context, the World Cup offers a short-cut: the chance to experience a new reality without struggle and reconciliation with little effort.

It became clear during my visit to South Africa in 2009 that local tourism authorities had replaced freedom struggle language with language more suited to building and strengthening the up-and-coming nation-state. They state South Africa's desire to join the roster of BRIC countries (Brazil, Russia, India, and China). Nation "branders" will be busy over the next several years. Questions concerning the identity of re-formed states and the place of globalized sporting events in nation building are not unique to South Africa or the African continent. These issues will continue to be important with Poland and Ukraine co-hosting the 2012 European Championships, Sochi the 2014 Winter Olympics, Brazil the 2014 World Cup, and Rio de Janeiro the 2016 Olympic Games.

SK: In psychological terms, I do think this is an “African” World Cup. That is, all over Africa many people will probably feel that this World Cup is in part theirs, that having it on their continent is recognition of their place in the world. I do think that many Ghanaians, say, are cheered by having a World Cup in South Africa rather than in Australia.

However, in practical terms the rest of Africa will have no benefit from this World Cup. The organizers have talked of teams playing warm-up friendlies or even holding training camps in neighboring countries like Botswana or Mozambique. I would be surprised if a single warm-up match were played there. Every coach wants to get his players to the best facilities in South Africa as fast as possible. The last thing he wants to do is spend a couple of days in a devastated country like Mozambique just before this huge tournament. Nor will many World Cup tourists travel around southern Africa.

I understand why the South African establishment and FIFA needed to use the rhetoric of an "African” World Cup. It is a concession to the other African countries, and matched Mbeki's rhetoric of an "African Renaissance.” However, in practical terms, this is not an African World Cup. In fact, South Africa was chosen as the host precisely because it is economically so different from the rest of Africa. I think that Gauteng, the region around Johannesburg and Pretoria, the hub of the World Cup, has three times the GDP per capita of any Sub-Saharan African country. South African exceptionalism in Africa is further accentuated by the fact that the games will mostly be held in formerly white neighborhoods, such as Green Point in Cape Town, Ellis Park in Johannesburg, and Loftus Versfeld in Pretoria.

FIFA and South Africa are determined that the facilities for the World Cup should be "first world"-or "world class,” in the favorite South African phrase. That means huge spending by South African taxpayers on stadiums, access roads, and hotels that often will not be needed the day the World Cup ends. Not that many people in towns outside the Gauteng area in more rural Rustenburg or Nelspruit attended football matches before the World Cup, and few will do so after it. That means the world-class infrastructure is wasteful spending in the long term.

RR: Infrastructurally, Cape Town is almost ready [January 31, 2010]. The completed stadium at Green Point was handed over to the City of Cape Town with the opening match between local professional clubs Santos and Ajax that took place in late January 2010. Road works have already been mentioned, the airport has been expanded, and new hotels built.

However, when the story of the "African” World Cup is told it will not be about stadiums and transport systems. It will be about the unique vibe and atmosphere that is African football. The people, the fans, the passion, the color, the rhythm, the deep love and enjoyment that the game evokes in the African spirit. That will be the real "African-ness" the rest of the world can expect. 


\section{Q3. What is your perception of football in South Africa and how have journalists shaped it?}

RR: Football is an integral part of the South African psyche. Unfortunately, it has often been tainted by stories of corruption and shoddy administration. In recent years, though, the administration has improved tenfold; the local PSL [Premier Soccer League] is a richly sponsored and well run operation. Allegations of corruption remain though, as attested to in recent allegations that there has been collusion between clubs and referees. The situation is being investigated though. However, the biggest problem in South African football is the lack of youth development. While many clubs have very good youth teams and coaching, there is no real commitment to development at a national level.

South African journalists are often nothing more than fans hiding behind a pen or a computer keyboard. There is little or no informed criticism or insightful analysis of the game. In addition, there have long been rumors that some journalists are simply mouthpieces for some club bosses. In short, journalists have not played an influential role in shaping the game, other than clouding fans with their own prejudices about teams or players.

SK: When I used to visit my grandparents in Johannesburg during the apartheid years, I did not have a perception of South African football because I was locked up in the ethnic group I belonged to, like everyone under apartheid, and in that group soccer barely existed. Whites had stopped going to watch local soccer in the late 1970s, when the game became integrated-more than 15 years ahead of the country-and crowds became mixed. They did not want to sit in stadiums in black townships, or risk consorting with black crowds at games. From the late 1970s, soccer barely existed for most white South Africans. They had their own sports, of course, particularly rugby and cricket.

What I have learned about football in South Africa I have learned mostly as a journalist since the early 1990s. This has been difficult, because most soccer fans in South Africa are from the black working classes, from whom I have been separated by language, place of residence, utterly different life experiences, and by fear. Given the high crime rate in South Africa, it is hard just to go to a township where you do not know anyone, hang out, and try to learn about soccer in South Africa that way. Nor are there many books about football in South Africa.

While local soccer media are very active, what has struck me is that international media know almost nothing about soccer in South Africa-as opposed to the preparations for the World Cup, which have been assiduously covered. In various magazines, I have read versions of the same article: journalist arrives in South Africa and attends the Chiefs-Pirates derby in Johannesburg and chronicles the ardor that exists for both teams, often by interviewing taxi drivers or white journalists. It is very hard for us foreigners to get deep into South African soccer. So most of what I know has been shaped by interviews I have done myself, or by reading South African media.

JT: My perception of football in the country is that it is more vital than the 2010 World Cup will acknowledge. Such landscape-altering events tend to devalue sport under the pretense of celebrating them. The World Cup, after all, is about watching football, not playing it. "The sun that never sets on the empire of modern passivity" is how Guy Debord defined the twentieth-century spectacle, which is not confined to World Cup soccer.

In 2010, I suspect that the textured history of football before and during apartheid will receive little attention. The same for women's football and the everyday football that occupies township streets. None of these issues has made it to North America, with the exception of some recent reporting from Geoffrey York in the Globe and Mail. Strange, since consciousness of South Africa's apartheid reality, at least in the United States, to large extent was mediated by the country's absence from international sporting festivals. 
For the football fantasist such as me, perceptions of football in South Africa and the continent have been shaped primarily through image: scratch goalposts beside shack settlements, scruffy and flattened balls at the feet of schoolchildren. Such pictures drive idyllic fantasies of those from non-football countries, making us forget that such features are not preconditions for African football. I am sure they would accept better pitches and equipment if they had them.

\section{Q4. How will the tournament affect the relationship between football and other dominant sporting codes in South Africa?}

RR: With football often playing stepchild to sporting codes like rugby and cricket in South African traditionally "white" media, the World Cup affords football the chance to take center stage, to imprint itself on the national psyche and identity in new ways. It will force the many people who treat the local game with disdain to get with the plot and embrace domestic football. In addition, who knows, perhaps after 2010, there will be many more followers of South African football among those who never deigned to give it a second thought before.

As rugby did in 1995, when it united the nation for a brief period, so, too, perhaps, football can use the World Cup to bring together a country still so fractured by the aftermath of apartheid. The rainbow nation proved to be premature after 1995, can South Africa find it again, and then make it more permanent?

SK: Currently there is an enormous disjunction in quality between South African soccer and the traditionally white sports. The rugby Springboks are world champions. The cricket Proteas are ranked number two in the world. Both teams are staffed largely by whites. South Africa's white golfers are also among the world's best. However, Bafana Bafana [“The Boys”], last time I checked, were ranked 86th in the world.

Clearly, this disjunction has to do with the intersection of race and class in South Africa. Until the first democratic elections in 1994, the white minority monopolized the vast majority of the country's resources, and the wealth gap in South Africa remains among the largest in the world. This means that members of black sports teams often have to struggle with poor nutrition, disease, inadequate training facilities, and grow up outside the knowledge networks of international football. By contrast, whites historically got the best of everything. Even white South African school teams would go on rugby or cricket tours abroad, so they were in the international knowledge networks.

I am worried that the World Cup will emphasize this racial divide: a weak, largely black, national soccer team in contrast with successful, largely white national teams in other major sports. All this points, of course, to the legacy of apartheid. The poor performance of soccer relative to other South African sports enhances white pride - it is mostly whites who care about the rugby and cricket teams - and diminishes black pride. On the other hand, you could also see the disjunction as a reversal of an almost universal stereotype: the notion that blacks are inherently more athletically gifted than whites.

JT: During the Confederations Cup in 2009, South African organizers boasted about the racial diversity among match spectators. They made sure to communicate that generalizations about soccer as black sport were outdated, which might presage similar rhetoric during the World Cup. With much of the live audience coming from Europe and North America, however, the argument will sound less convincing.

I am not conversant with domestic rugby and cricket and how their followings might be affected. However, another important question is the tournament's potential impact on women's football. Fran Hilton-Smith, South Africa's senior women's coach, is optimistic that momentum exists for a national, rather than provincial, 
women's league. She also predicts that the country will bid for the Women's World Cup, perhaps as soon as 2015.

\section{Q5. How do mainstream and alternative media (including blogs, Facebook, and Twitter) differ in their coverage and representation of 2010 and of South Africa itself?}

SK: I see two main themes in the global mainstream media in the run-up to the tournament: (1) Will South Africa be ready for the tournament? and (2) Crime. There have been many newspaper articles and TV items on both issues over the last couple of years. What you see is that these reports are often countered online by nationalistic South Africans, often whites, simply because on average white South Africans still have much more access to the Internet than black South Africans. These South Africans write blogs or comments after critical articles (e.g., about crime) in which they defend their country against the foreign criticism. A favorite debating point of these South Africans is to say, "Well, there's crime everywhere. Look at the people who get knifed in London.” This argument of course ignores basic statistics: yes, there is violent crime everywhere, but there is a lot more of it in South Africa than in most other places.

The point is that individual South Africans online frequently defend their country. (See the reader responses on the Guardian's football Web site, for instance, or the angry e-mails I get from South African readers whenever I write anything critical about the country.) I think this partly stems from an apartheidera mentality among some whites: “The world is always criticizing South Africa, but only we can really know what it's like here.” In addition, it stems in part from the patriotism, pride, and sporting nationalism that the new South Africa has successfully created.

JT: Blogs and social-networking tools in my experience serve mainly as echo chambers for mainstream media. I expect them to function no differently during the 2010 tournament. To the extent that social media infiltrate, FIFA no doubt will have a strong presence; otherwise, expect millions of banal tweets complaining about traffic and long queues for transit.

Will attention afforded the country provide an opportunity for citizen journalists, especially those writing outside the major cities and in languages other than English? I would be interested to learn from South Africa's blogging community. I do not know the answer.

RR: I am not much of a social media person so I cannot comment except to underscore the point that mainstream media in South Africa have essentially embraced the tournament, and their coverage, in the main, has been positive. Space is given to the odd critical debate, but all in all the media is fully behind the country's World Cup experience.

\section{Q6. What is the most memorable story about the World Cup in South Africa you have come across so far?}

RR: I think all over the country people are preparing in their own way and writing and telling their own World Cup stories in their own unique, individual way. For me, the World Cup draw in Cape Town [in December 2009] and the way it was embraced, followed, and celebrated by Capetonians was just magnificent. It showed 
how if South Africans are given a cause or something they care about to get behind then they go all the way, no half measures. The Long Street party (in downtown Cape Town) for the draw was supposed to attract 15,000 people and we came with 45,000. The way we wowed the world with what we could do on that day astounded me; and if that is an indication of the World Cup, then bring it on

JT: Tellingly, the best story has nothing to do with the World Cup, but involves a day spent with Chosen Few Lesbian Soccer Club of Johannesburg in June 2009. That a club of openly gay women, affiliated with the Forum for the Empowerment of Women at Constitution Hill, could travel in two vans for a friendly in Rustenburg, in North West province, speaks well of progressive trends in new South Africa. While players report previous harassment-whether or not they anticipated trouble, local police patrolled this match against a provincial side - the game took place in good spirit, with 70 spectators enjoying the day. Despite a 6-1 drubbing, Chosen Few threw open the van doors afterward, adding to the blare of pitchside stereos. They smoked cigarettes and shared red wine from Styrofoam cups.

The side has travelled to international tournaments. Players are educated in advocating for lesbian, bisexual, and transgender rights. In a culture that tells gay women to "keep your lesbianism to yourself," says Coach Tapuwa Moore, points to football's potential for communication. She wants her players to witness to truth as they break two taboos in South African culture: that football is for men only, and that heterosexuality forms the basis for a decent life.

SK: John Turnbull, editor of theglobalgame.com, did a great interview in South Africa with Kaizer Motaung last year, in which Motaung told him how the idea of hosting the World Cup in South Africa first came up. Motaung, founder of the country's most popular club, and Solomon "Stix" Morewa, then head of the South African Football Association, and a few other South African soccer officials were in the USA for the 1994 World Cup, just a few weeks after the first black majority government had been elected. They saw the excitement of the World Cup, and they said to each other, "Why can't we have one in South Africa?” I really like that story because it shows the chutzpah of the new South Africa-the sense that it should be at the heart of world events, that it can do everything, that the world would instinctively want a World Cup in South Africa, because South Africa is more than just another country-it's a model for our multiracial world. However critical I am of the wasteful spending of the South African World Cup, I love that self-belief.

\section{Q7. Who will win the World Cup?}

SK: Brazil, surely?

RR: Brazil, who else?

JT: With apologies for lack of imagination: Brazil.

\section{Afterword, with Rodney Reiners and John Turnbull}

RR: I would like to respond to John Turnbull's answers based on his conversations with people in Cape Town. Spatially, South Africa is grievously wounded because of the fiendishly clever geographic manipulation and social engineering of the apartheid regime. In addition, today the country labors under these painful constraints. Having said that, a World Cup stadium in Khayelitsha or Athlone [black working poor areas] just would not 
make sense because it would be located in the middle of dense residential areas, thereby creating many serious problems that would eventually detract from a proper, exciting World Cup experience.

This past Saturday [January 23, 2010], the new World Cup venue in Green Point opened with a friendly match between local sides Santos and Ajax Cape Town. It was an occasion to savor and be proud of. People of all hues, including many families, flocked to the ground, to feel part of history. It was something to make Capetonians proud.

John spoke of a lack of proper development and about the paucity of recreational opportunities. The truth is also that Cape Town has one of the most vibrant football communities in the entire country. More people play football than rugby in this city. There are amateur football clubs all over, for kids under age seven right up to senior level. All kids have to do is join and play, often at no cost at all. All they need is the will and the desire. Schools offer soccer programs as well, and the same will and desire are required. If "the children are sitting around," it is often their own fault or the fault of their parents. Yes, there is still a battle with poverty and still so much of South Africa battles to overcome the inequalities left by apartheid. Lack of vision and ambition among kids and their parents play a role too. Some youths damage schools and facilities in black townships, show little or no respect for their elders, and gangs and crime are often more attractive outlets to many of them than oldfashioned hard work. Aspiration and perspiration are what is needed in South Africa, rather than the victim narratives that permeate so much of our society. Opportunities abound all over the place, they just have to be recognized, and worked hard at.

JT: I defer to Rodney on geographic realities in South Africa and on the legacy of apartheid planners. In the Western Cape, however, I note that provincial leaders originally proposed an upgraded Athlone Stadium in Cape Flats as a World Cup site. FIFA refused.

I wonder what a "proper, exciting World Cup experience" entails these days. With globalization and commercialization of world football in the [FIFA presidents] Havelange and Blatter eras, the range of acceptable behaviors has narrowed. Corporate backers control the stadium and immediate vicinity. Clearly, no spectator should feel threatened at World Cup venues; safety and security are critical concerns. However, emphasis has shifted from authenticity and spontaneity to certainty of consumption. FIFA, country branders, and sponsors want a sure thing. The bottom line depends on it.

Concerning Cape Town football, I admit some ambivalence about the concrete social benefits that an event the scale of the World Cup must provide. Doesn't every society have the right to stage the festival of its choosing, at the place of its choosing? Moreover, my reading, though, of the situation in Khayelitsha and outlying areas in Cape Town is different. I see a resourceful, self-sufficient community of vast potential that suffers from entrenched inequities. Yes, the apartheid legacy endures, but investment from the present leadership would help. To the extent that football still supplies visions of transcendence, the World Cup gives South Africans the chance to model a more inclusive ideal of city and country.

\section{Notes}

1. This roundtable, intended as a discussion piece to complement the peer-reviewed research articles in the rest of this special issue, was facilitated by Peter Alegi and Chris Bolsmann, with Simon Kuper, Rodney Reiners, and John Turnbull as participants. 